\title{
Microbiome evaluation revealed salivary dysbiosis in addicts of betel nut preparations
}

Faizan Saleem ${ }^{1}$, Ghulam Mujtaba ${ }^{2}$, Junaid Ahmed Kori ${ }^{2 \#}$, Arshad Hassan ${ }^{3}$, and M. Kamran Azim $^{1 *}$

${ }^{1}$ Department of Biosciences, Mohammad Ali Jinnah University, Karachi, Pakistan. ${ }^{2}$ H.E.J. Research Institute of Chemistry, International Center for Chemical and Biological Sciences, University of Karachi, Karachi, Pakistan. ${ }^{3}$ Dow Dental College, Dow University of Health Sciences, Karachi, Pakistan.

*Corresponding author Email: kamran.azim@jinnah.edu; mkamranazim@yahoo.co.uk

\begin{abstract}
Betel nut addiction is recognized as the causative agent of oral microbiome dysbiosis and other systematic disorders. A number of betel nut preparations containing ingredients such as slaked lime, catechu extract and tobacco are being commonly used particularly in South Asia. The underlying variations in the oral microbiome due to usage of betel nut preparations are poorly understood. We evaluated salivary microbiome in response to chewing of betel nut preparation(s). In order to assess the microbiome dynamics, metagenomic analysis of 16S rRNA gene (V3-V4 hypervariable region) from salivary bacteria in chewers of betel nut preparation (n $=16)$ and non-chewers $(n=55)$ was carried out by Greengenes and SILVA ribosomal sequence databases. It was observed that Gutka chewers demonstrated lower alpha diversity and number of bacterial genera than the non-chewers. Taxonomic assignment on phylum level revealed Firmicutes ( $p$-value $=0.042$ at $95 \%$ confidence interval) to be significantly more abundant in Gutka chewers in comparison with non-chewers. Beta diversity analysis at genus level by weighted unifrac distance matrices unveiled both groups to be divergent from each other. On the genus level, Veillonella $(\mathrm{p}$-value $=0.015)$, Streptococcus $(\mathrm{p}$-value $=0.026)$, Leptotrichia $(\mathrm{p}$ value $=0.022)$ and Serratia $(\mathrm{p}$-value $=0.022)$ species appeared to be significantly more abundant in Gutka chewers in comparison to non-chewers. The present study suggests salivary dysbiosis in response to gutka chewing and concludes that gutka chewers possess higher abundance of acidogenic and aciduric bacteria. This study contributes additional information regarding oral microbiome variations with response to gutka consumption.
\end{abstract}


medRxiv preprint doi: https://doi.org/10.1101/2020.04.13.20064063; this version posted April 17, 2020. The copyright holder for this preprint (which was not certified by peer review) is the author/funder, who has granted medRxiv a license to display the preprint in perpetuity.

All rights reserved. No reuse allowed without permission.

Keywords: Oral microbiome; betel nut; Next generation sequencing; metagenomics; 16S rRNA

\section{Introduction}

Betel nut consumption is practiced by $10-20 \%$ of the world's total population and commonly associated with Asian-pacific region ${ }^{1}$. Betel nut (also known as areca nut) has been classified as a group I carcinogen by international agency of cancer research (IARC) and is proposed to generate dependency in consumers ${ }^{2}$. Components of Betel nut have previously been correlated with pro-carcinogenic variations, reactive oxygen species production and immuno-modulatory disruptions ${ }^{3}$. Hence, betel nut chewing is detrimental for oral health by inducing inflammatory responses and periodontal disorders ${ }^{4}$.

Asia pacific region is Hub for a variety of betel nut preparations. In addition to betel nut, the preparations are comprised of slaked lime, catechu, spices and tobacco ${ }^{5}$. Among these preparations 'Gutka' (containing betel nut, lime, catechu, sandalwood and tobacco), "Mawa" (containing betel nut, tobacco and slaked lime) and "Paan" (betel nut, slaked like, catechu extract wrapped in piper leaf with or without tobacco) are common in Indian subcontinent ${ }^{6,7}$. According to the epidemiological studies carried out in past few decades, $\sim 20-40 \%$ population of Pakistan, Nepal and India consume these preparations ${ }^{8}$.

Habitual users of gutka experience higher periodontal inflammation, gum bleeding and marginal bone loss that lead to a number of diseases including oral submucosal fibrosis, dental caries and oral cancer ${ }^{9}$. Ingredient of Gutka preparations have been reported to be involved in oral health impairment. Slaked lime promotes production of reactive oxygen species and betel nut extract disrupts the functionality of periodontal fibroblasts, thus leading to increased rate of inflammation and carcinogenesis?

The human oral microbiome is composed of 700 different bacterial genera among which $32 \%$ phylotypes are unculturable ${ }^{10,11}$. These bacterial communities play a role in maintaining normal oral homeostasis including defense against pathogens, inflammatory response regulation and neutralization of reactive nitrogen species ${ }^{12}$. Several studies have proclaimed the prominence of oral microbiome in development of oral systematic disorders such as gingivitis, dental caries and periodontitis $^{13}$. A number of factors such as lifestyle habitats and tobacco usage can alter the oral 
medRxiv preprint doi: https://doi.org/10.1101/2020.04.13.20064063; this version posted April 17, 2020. The copyright holder for this preprint (which was not certified by peer review) is the author/funder, who has granted medRxiv a license to display the preprint in perpetuity.

All rights reserved. No reuse allowed without permission.

microbiome ${ }^{14}$. Consumption of betel nut preparations is among the factors that are responsible for dysbiosis of oral microbiome, thus disrupting the normal oral homeostasis ${ }^{15}$.

However, the alteration of oral microbiome in response to consumption of betel nut preparations such as Gutka is poorly understood. The objective of present study was salivary microbiome evaluation in addicts of betel nut preparations.

\section{Materials and Methods}

\subsection{Study Population and Sample Collection}

The study was sanctioned by Independent Ethics Committee, International Center for Chemical and Biological Sciences, University of Karachi, Pakistan (Study no. 011-SS-2016. Protocol no. ICCBS/IEC-011-SS-2016/Protocol/1.0). The studied population included individuals residing in Karachi, Pakistan within the age limit of 25-40. Studied participants were recruited in the interval of two years from January 2017 to December 2018. Verbal screening of participants was carried out and written informed consent was obtained. In brief, participants chewing Gutka for more than one year with a chewing frequency of at least 5 times/day and consumption of at least 20 gram/day were selected. For non-chewers $(n=55)$, the individuals having un-controlled HbA1c levels (i.e. HbA1c > 6.0), acute or chronic illnesses, periodontal diseases, tobacco usage, pregnancy and antibiotic usage were not included in the study. For the gutka chewers $(\mathrm{n}=16)$, individuals having current infectious conditions (i.e. white cell count > 11), smoking habit, pregnancy, medication usage, cancerous malignancies, immunosuppression or immunodeficiency treatment and usage of any form of steroids were excluded from the study.

HbA1c estimation of each participant was carried out by Hitachi 902 auto-analyzer. Unstimulated saliva samples were obtained from participants in sterilized $15 \mathrm{~mL}$ conical tubes and stored at $-20{ }^{\circ} \mathrm{C}$ till the extraction of bacterial DNA.

\subsection{DNA Extraction and PCR Amplification}

Metagenomic DNA was extracted from saliva samples by using ORAgene DNA extraction kit (DNA Genotek Inc, Ontario, Canada). Quality assessment of extracted DNA was carried out by $1 \%$ agarose gel electrophoresis. DNA quantification was performed by Qubit fluorimeter 2.0 (Invitrogen Inc. USA). The V3-V4 hypervariable region of 16S rRNA gene was amplified 
medRxiv preprint doi: https://doi.org/10.1101/2020.04.13.20064063; this version posted April 17, 2020. The copyright holder for this preprint (which was not certified by peer review) is the author/funder, who has granted medRxiv a license to display the preprint in perpetuity.

All rights reserved. No reuse allowed without permission.

according to the instructions in '16S Metagenomics Sequencing Library Preparation guidelines' (Illumina Inc. USA) by T100 thermal cycler (BioRad, USA).

\subsection{S rDNA Library Preparation and Sequencing}

16S rDNA amplicons were used for index PCR by Nextera XT index kit (Illumina Inc., USA). A final reaction of $50 \mu 1$ was prepared with $5 \mu 1$ amplicon, $5 \mu 1$ index primer $1,5 \mu 1$ index primer 2 , $25 \mu 12 X$ KAPA Hot-Start master mix and $10 \mu 1$ PCR grade water. Index PCR program was set as, preheating for 3 minutes at $95^{\circ} \mathrm{C}, 8$ cycles of initial denaturation at $95^{\circ} \mathrm{C}$ for 30 seconds, annealing for 30 seconds at $55{ }^{\circ} \mathrm{C}$, extension for 30 seconds at $72{ }^{\circ} \mathrm{C}$ and final extension for 5 minutes at $72^{\circ} \mathrm{C}$. Index PCR clean-up was carried by AMPure XP magnetic beads (Beckman Coulter Inc., USA) according to instructions in ' $16 \mathrm{~S}$ Metagenomics Sequencing Library Preparation' guidelines. Cleaned indexed amplicons were diluted to 4nmol concentration followed by pooling. Final pooled library was sequenced by Illumina MiSeq system using V3 reagent kit (Illumina Inc., USA).

\subsection{Bioinformatics and Statistical Analysis}

MiSeq sequencing resulted in 2X300 nts paired-end reads. Quality assessment of paired-end NGS reads was carried out by FASTQC software (Andrews, 2010). NGS reads with poor quality $(\mathrm{q}<20)$ were filtered using Trimmomatic program ${ }^{16}$, followed by removal of chimeric sequences via UCHIME program $^{17}$. QIIME2 microbiome bioinformatics platform was utilized for downstream analysis of filtered reads ${ }^{18}$. Sequences with length shorter than 200 bases and ambiguous bases were removed by DADA2 denoising tool ${ }^{19}$. Greengenes and SILVA ribosomal sequence databases were utilized for taxonomic assignment through RDP classifier in QIIME2 ${ }^{20-}$ 22.

Alpha diversity indices were calculated using Shannon-Weaver and Simpson's reciprocal methods $^{23}$, while beta diversity among the samples was measured according to weighted UniFrac distance matrices ${ }^{24}$. Extended error bar plots for differentially abundant taxa at phylum and genus level were constructed according to Welch's t-test at $95 \%$ confidence interval with Storey's FDR correction using STAMP statistical tool ${ }^{25}$.

\section{Results}


medRxiv preprint doi: https://doi.org/10.1101/2020.04.13.20064063; this version posted April 17, 2020. The copyright holder for this preprint (which was not certified by peer review) is the author/funder, who has granted medRxiv a license to display the preprint in perpetuity.

All rights reserved. No reuse allowed without permission.

Oral examination of participants was carried out at the time of saliva collection. Figure 1 represents oral lesions in gukta chewers. Red erythroplakia of buccal mucosae, stains of gutka preparation and gutka deposition in dental plaque can be seen in the images.

\subsection{S rDNA Sequencing and Assessment of Alpha Diversity}

Filtration of low quality next-generation sequence (NGS) reads (i.e. q<20) resulted in 4,175,739 and 715,460 paired-end reads from salivary samples of non-chewers $(n=55)$ and Gutka chewers $(n=16)$, respectively. The read lengths of filtered NGS sequences were 250-300 nucleotides. Table 1 demonstrates the number of NGS reads and alpha diversity indices (Shannon-Weaver and Simpson's methods) for both groups. The total number of genera in both groups were identified in order to evaluate bacterial diversity. Figure 2 demonstrates the VENN diagram of bacterial genera identified in Gutka chewers and non-chewers. In total, 234 and 75 bacterial genera were detected in non-chewers and Gutka chewers, respectively. Sixty-four genera were common between both groups, while 170 genera were unique for non-chewers and 11 genera were exclusively observed in Gutka chewers. Bacterial genera exclusively detected in gutka chewers were Anaerophaga, Ancylomarina, Anoxybacillus, Bifidobacterium, Cellulosilyticum, Hyphomonas, Marinifilum, Mesocricetibacter, Pelomonas, Peptoniphilus, Scardovia. Shannon-

Weaver and Simpson's alpha diversity indices represent variations in bacterial diversity within the samples ${ }^{23}$. On average, alpha diversity (Simpson's reciprocal index) for saliva of non-

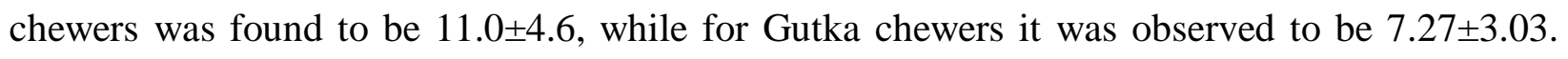
Hence, the Gutka chewers demonstrated lower alpha diversity in comparison to non-chewers.

NGS reads were assigned to their respective taxonomic groups in order to unravel the bacterial diversity trends amidst non-chewers and Gutka chewers. Welch's t-test with Storey's FDR correction at $95 \%$ confidence interval was applied to characterize significant variation of bacterial phyla amongst both groups (Figure 3a). No significant change in abundance of Bacteroidetes $(\mathrm{p}$-value $=0.378)$ and Proteobacteria $(\mathrm{p}$-value $=0.949)$ was observed in both groups, while sequences related to Firmicutes $(\mathrm{p}$-value $=0.042)$ were significantly higher in Gutka chewers.

\subsection{Bacterial Diversity at Genus Level}

Bacterial diversity at genus level was measured by weighted UniFrac distance matrix (WUDM) to determine the beta diversity patterns amongst Gutka chewers and non-chewers. Weighted 
medRxiv preprint doi: https://doi.org/10.1101/2020.04.13.20064063; this version posted April 17, 2020. The copyright holder for this preprint (which was not certified by peer review) is the author/funder, who has granted medRxiv a license to display the preprint in perpetuity.

All rights reserved. No reuse allowed without permission.

UniFrac distance matrix calculates the diversity among the samples based on the differentially abundant $\operatorname{taxa}^{24}$. The data generated by WUDM was utilized to construct PCoA plot. In the PCoA plot, samples from non-chewers clustered together, while samples from Gutka chewers scattered in two regions (figure 4). Samples of Gutka chewers remained divergent from the nonchewers cluster, which is an indicator of dissimilarity of bacterial diversity between both groups.

To characterize the statistical abundance profile of bacterial genera in both groups Welch's t-test with Storey's FDR correction (95\% confidence interval) was applied. The abundance of 4 bacterial genera was found to be significantly elevated in Gutka chewers (Figure 3b). These bacterial genera were Serratia $(\mathrm{p}$-value $=0.022)$, Veillonella $(\mathrm{p}$-value $=0.015)$, Streptococcus $(\mathrm{p}-$ value $=0.026)$ and Leptotrichia $(\mathrm{p}$-value $=0.022$ ). Whereas, the population of four bacterial genera decreased in Gutka chewers which were Neisseria (p-value $=0.022)$, Alloprevotella $(\mathrm{p}$ value $\left.=2.16 \times 10^{-6}\right)$, Pseudomonas $(\mathrm{p}$-value $=0.011)$ and Fusobacterium $(\mathrm{p}$-value $=0.015)$.

\section{Discussion}

Oral cavity provides a microenvironment for the growth of hundreds of bacterial species ${ }^{11}$. These oral bacterial communities play a role in sustainability of normal oral homeostatic state. However, many intrinsic and environmental factors could stimulate microbial changes and lead to dysbiosis ${ }^{26}$.

In the present study, the salivary microbiome of chewers of betel nut preparations "Gutka" $(n=16)$ and non-chewers $(n=55)$ was analyzed by using 16S rDNA metagenomics approach. Both alpha diversity indices (i.e. Shannon-Weaver and Simpson's) appeared to be lower for the betel nut addict individuals in comparison to non-addicts (table 1). Furthermore, before number of unique bacterial genera were also found to be lower for gutka chewers (figure 2), which is suggestive of decrease in oral microbiome diversity in response to gutka chewing. Among the body sites, oral cavity is known to possess diverse bacterial population as indicated by higher alpha diversity values ${ }^{27}$. In the present study, we found decreased diversity of bacterial communities in saliva of gutka chewers in comparison to non-chewers. Recently, it has been reported that decrease in alpha diversity is correlated with onset and progression of dental caries $^{28}$.

Among the bacterial phyla, Firmicutes were found to be significantly higher in abundance in gutka chewers than in non-chewers (Figure 3a). These findings are in support of a previous 
medRxiv preprint doi: https://doi.org/10.1101/2020.04.13.20064063; this version posted April 17, 2020. The copyright holder for this preprint (which was not certified by peer review) is the author/funder, who has granted medRxiv a license to display the preprint in perpetuity.

All rights reserved. No reuse allowed without permission.

study, which reported similar oral microbial patterns in patients suffering from metabolic syndrome $^{29}$. Furthermore, abundance of oral Firmicutes population is also previously reported in correlation with elevated levels of inflammation ${ }^{30}$. In a previous study from USA, Actinobacteria phylum was depicted to be second most abundant oral bacterial phylum associated with betel nut chewing $^{15}$. In contrast, our results did not indicate any significant correlation of Actinobacteria population in response to consumption of betel nut preparation (Gutka).

Beta diversity measurement (Weighted uniFrac Distance Matrix) demonstrated that both groups are in separate clusters indicating substantial variations in salivary microbiome on the genus level (Figure 4). The abundance of Serratia ( $p$-value $=0.022)$, Veillonella $(p$-value $=0.015)$, Streptococcus $(p$-value $=0.026)$ and Leptotrichia $(p$-value $=0.022)$ bacterial genera was found to be significantly associated with gutka chewers (Figure 3b). Our results are in agreement with a previous study which by using denaturing gradient gel electrophoresis (DGGE) correlated the abundance of Streptococcus and Veillonella in response to usage of betel nut preparations ${ }^{31}$. Serratia species are gram-negative, facultatively anaerobic bacteria possessing the ability to act as opportunistic pathogens in immunocompromised patients. These bacteria are found in oral cavities of patients suffering from chronic periodontitis ${ }^{32}$. Veillonella species are strictly anaerobic, biofilm-producing and aciduric bacteria that thrive in correlation with acidogenic bacterial species such as Streptococci ${ }^{33}$. Acidogenic species such as Streptococci and Leptotrichia dissimilate salivary disaccharides into simpler monosaccharides (i.e. glucose) followed by conversion of glucose into organic acids (i.e. lactate), which in turn is then utilized by Veillonella species as the energy and carbon source for growth ${ }^{34,33}$. Furthermore, Veillonella species can adhere to teeth and gums by using dextran produced by Streptococci through the action of their glucosyltransferases on sucrose ${ }^{35}$. Leptotrichia species are facultatively anaerobic, acidogenic bacteria which act as causative agents of oral lesions and dental caries in immunocompromised patients ${ }^{34}$. A consortium of these acidogenic and aciduric bacterial genera in Gutka chewers may contribute in deterioration of oral and dental health.

The present study provides additional information related to oral microbial dysbiosis in Gutka chewers, which might be helpful in further assessment of oral complications that arise due to consumption of betel nut preparations.

\section{Acknowledgments:}


medRxiv preprint doi: https://doi.org/10.1101/2020.04.13.20064063; this version posted April 17, 2020. The copyright holder for this preprint

We thank all participants of this study.

\section{Conflict of interest:}

Authors declare no conflict of interest.

\section{References}

1. Islam, S., Muthumala, M., Matsuoka, H., Uehara, O., Kuramitsu, Y., Chiba, I. and Abiko, Y. (2019) How Each Component of Betel Quid Is Involved in Oral Carcinogenesis: Mutual Interactions and Synergistic Effects with Other Carcinogens-a Review Article. Curr Oncol Rep, 21(6), 53. https://doi.org/10.1007/s11912-019-0800-8

2. Mehrtash, H., Duncan, K., Parascandola, M., David, A., Gritz, E.R., Gupta, P.C., Mehrotra, R., Nordin, A.S.A., Pearlman, P.C., Warnakulasuriya, S. and Wen, C.P. (2017) Defining a global research and policy agenda for betel quid and areca nut. Lancet Oncol, 18(12), e767-e775. https://doi.org/10.1016/S1470-2045(17)30460-6

3. Secretan, B., Straif, K., Baan, R., Grosse, Y., El Ghissassi, F., Bouvard, V., BenbrahimTallaa, L., Guha, N., Freeman, C., Galichet, L. and Cogliano, V. (2009) A review of human carcinogens--Part E: tobacco, areca nut, alcohol, coal smoke, and salted fish. Lancet Oncol, 10(11), 1033.

4. Dawani, N., Nisar, N., Khan, N., Syed, S. and Tanweer, N. (2012) Prevalence and factors related to dental caries among pre-school children of Saddar town, Karachi, Pakistan: a cross-sectional study. BMC Oral Health, 12(1), 59. https://doi.org/10.1186/1472-6831$\underline{12-59}$

5. Blank, M., Deshpande, L. and Balster, R.L. (2008) Availability and characteristics of betel products in the US. J Psychoactive Drugs, 40(3), 309-313. https://doi.org/10.1080/02791072.2008.10400646

6. Sarode, S.C., Mahuli, A., Sarode, G.S. and Mahuli, S. (2013) Why only areca nut chewing cannot cause oral submucous fibrosis?. Med Hypotheses, 81(1), 47-49. https://doi.org/10.1016/j.mehy.2013.02.025

7. Madathil, S.A., Rousseau, M.C., Allison, P., Netuveli, G., Humphris, G.M., Varghese, I., Shiraz, S., Castonguay, G., Thekkepurakkal, A.S., Shahul, H.P. and Nicolau, B., 2015. Maternal and paternal contribution to intergenerational psychosocial transmission of paan 
medRxiv preprint doi: https://doi.org/10.1101/2020.04.13.20064063; this version posted April 17, 2020. The copyright holder for this preprint

chewing. Community dentistry and oral epidemiology, 43(4), 289-297. http://doi.org/10.1111/cdoe.12153

8. Lee, C.H., Ko, A.M.S., Warnakulasuriya, S., Yin, B.L., Zain, R.B., Ibrahim, S.O., Liu, Z.W., Li, W.H., Zhang, S.S., Utomo, B. and Rajapakse, P.S. (2011). Intercountry prevalences and practices of betel-quid use in south, southeast and eastern Asia regions and associated oral preneoplastic disorders: an international collaborative study by Asian betel-quid consortium of south and east Asia. Int J Cancer, 129(7), 1741-1751. https://doi.org/10.1002/ijc.25809

9. Javed, F., Vohra, F., Al-Kheraif, A.A., Malmstrom, H. and Romanos, G.E. (2015). Comparison of periodontal inflammatory conditions among habitual gutka chewers and betel quid chewers. Oral Dis, 21(4), 437-442. https://doi.org/10.1111/odi.12295

10. Simon-Soro, A., Tomás, I., Cabrera-Rubio, R., Catalan, M.D., Nyvad, B. and Mira, A. (2013). Microbial geography of the oral cavity. J Dent Res, 92(7), 616-621. https://doi.org/10.1177/0022034513488119

11. Kilian, M., Chapple, I.L.C., Hannig, M., Marsh, P.D., Meuric, V., Pedersen, A.M.L., Tonetti, M.S., Wade, W.G. and Zaura, E. (2016) The oral microbiome-an update for oral healthcare professionals. British Dent J, 221(10), 657. https://doi.org/10.1038/sj.bdj.2016.865

12. Vanhatalo, A., Blackwell, J.R., L'Heureux, J.E., Williams, D.W., Smith, A., van der Giezen, M., Winyard, P.G., Kelly, J. and Jones, A.M. (2018). Nitrate-responsive oral microbiome modulates nitric oxide homeostasis and blood pressure in humans. Free Radical Bio Med, 124, 21-30. https://doi.org/10.1016/j.freeradbiomed.2018.05.078

13. Wade, W.G. (2013) The oral microbiome in health and disease. Pharmacological Research 69, no. 1, 137-143. https://doi.org/10.1016/j.phrs.2012.11.006

14. Scannapieco, F.A. (2013). The oral microbiome: its role in health and in oral and systemic infections. Clin Microbiol Newsl, 35(20), 163-169. https://doi.org/10.1016/j.clinmicnews.2013.09.003

15. Hernandez, B.Y., Zhu, X., Goodman, M.T., Gatewood, R., Mendiola, P., Quinata, K. and Paulino, Y.C. (2017) Betel nut chewing, oral premalignant lesions, and the oral microbiome. PloS ONE, 12(2), e0172196. https://doi.org/10.1371/journal.pone.0172196 
medRxiv preprint doi: https://doi.org/10.1101/2020.04.13.20064063; this version posted April 17, 2020. The copyright holder for this preprint (which was not certified by peer review) is the author/funder, who has granted medRxiv a license to display the preprint in perpetuity. All rights reserved. No reuse allowed without permission.

16. Bolger, A.M., Lohse, M. and Usadel, B. (2014). Trimmomatic: a flexible trimmer for Illumina sequence data. Bioinformatics, 30(15), 2114-2120. https://doi.org/10.1093/bioinformatics/btu170

17. Edgar, R.C., Haas, B.J., Clemente, J.C., Quince, C. and Knight, R. (2011). UCHIME improves sensitivity and speed of chimera detection. Bioinformatics, 27(16), 2194-2200. https://doi.org/10.1093/bioinformatics/btr381

18. Bolyen, E., Rideout, J.R., Dillon, M.R., Bokulich, N.A., Abnet, C., Al-Ghalith, G.A., Alexander, H., Alm, E.J., Arumugam, M., Asnicar, F. and Bai, Y. (2018). QIIME 2: Reproducible, interactive, scalable, and extensible microbiome data science. No. e27295v1. PeerJ Preprints.

19. Callahan, B.J., McMurdie, P.J., Rosen, M.J., Han, A.W., Johnson, A.J.A. and Holmes, S.P. (2016). DADA2: high-resolution sample inference from Illumina amplicon data. Nat Methods, 13(7), 581. https://doi.org/10.1038/nmeth.3869

20. McDonald, D., Price, M.N., Goodrich, J., Nawrocki, E.P., DeSantis, T.Z., Probst, A., Andersen, G.L., Knight, R. and Hugenholtz, P. (2012). An improved Greengenes taxonomy with explicit ranks for ecological and evolutionary analyses of bacteria and archaea. ISME J, 6(3), 610. https://doi.org/10.1038/ismej.2011.139

21. Quast, C., Pruesse, E., Yilmaz, P., Gerken, J., Schweer, T., Yarza, P., Peplies, J. and Glöckner, F.O. (2012). The SILVA ribosomal RNA gene database project: improved data processing and web-based tools. Nucleic Acids Res, 41(D1), 590-596. https://doi.org/10.1093/nar/gks1219

22. Lan, Y., Wang, Q., Cole, J.R. and Rosen, G.L. (2012) Using the RDP classifier to predict taxonomic novelty and reduce the search space for finding novel organisms. PLoS ONE, 7(3), e32491. https://doi.org/10.1371/journal.pone.0032491

23. Marcon, E., Scotti, I., Hérault, B., Rossi, V. and Lang, G. (2014) Generalization of the partitioning of Shannon diversity. PloS ONE, 9(3), e90289. https://doi.org/10.1371/journal.pone.0090289

24. Lozupone, C., Lladser, M.E., Knights, D., Stombaugh, J. and Knight, R. (2011) UniFrac: an effective distance metric for microbial community comparison. ISME J, 5(2), 169. https://doi.org/10.1038/ismej.2010.133 
medRxiv preprint doi: https://doi.org/10.1101/2020.04.13.20064063; this version posted April 17, 2020. The copyright holder for this preprint (which was not certified by peer review) is the author/funder, who has granted medRxiv a license to display the preprint in perpetuity.

25. Parks, D.H., Tyson, G.W., Hugenholtz, P., \& Beiko, R.G. (2014) STAMP: statistical analysis of taxonomic and functional profiles. Bioinformatics, 30(21): 3123-3124. https://doi.org/10.1093/bioinformatics/btu494

26. Perera, M., Al-hebshi, N.N., Speicher, D.J., Perera, I. and Johnson, N.W. (2016) Emerging role of bacteria in oral carcinogenesis: a review with special reference to periopathogenic bacteria. J Oral Microbiol, 8(1), 32762. https://doi.org/10.3402/jom.v8.32762

27. Moon, J.H. and Lee, J.H. (2016) Probing the diversity of healthy oral microbiome with bioinformatics approaches. BMB Rep, 49(12), 662. http://doi.org/ 10.5483/BMBRep.2016.49.12.164

28. Hurley, E., Barrett, M.P., Kinirons, M., Whelton, H., Ryan, C.A., Stanton, C., Harris, H.M. and O'Toole, P.W. (2019) Comparison of the salivary and dentinal microbiome of children with severe-early childhood caries to the salivary microbiome of caries-free children. BMC Oral Health, 19(1), 13. https://doi.org/10.1186/s12903-018-0693-1

29. Si, J., Lee, C. and Ko, G. (2017) Oral microbiota: microbial biomarkers of metabolic syndrome independent of host genetic factors. Front Cell Infect Mi, 7, 516. https://doi.org/10.3389/fcimb.2017.00516

30. Demmer, R.T., Breskin, A., Rosenbaum, M., Zuk, A., LeDuc, C., Leibel, R., Paster, B., Desvarieux, M., Jacobs, J.D.R., \& Papapanou, P.N. (2017) The subgingival microbiome, systemic inflammation and insulin resistance: the oral infections, glucose intolerance and insulin resistance study. J Clin Periodontol, 44(3), 255-265. https://doi.org/10.1111/jcpe.12664

31. Xiong, X., Hou, A., Yi, S., Guo, Y., Zhao, Z., Wu, Z., Cheng, H., Li, K., Li, Z., Ren, Y. and Wang, Y. (2018) Analysis of oral microorganism diversity in healthy individuals before and after chewing areca nuts using PCR-denatured gradient gel electrophoresis. Animal nutrition, 4(3), 294-299. https://doi.org/10.1016/j.aninu.2018.07.001

32. van Winkelhoff, A.J., Rurenga, P., Wekema-Mulder, G.J., Singadji, Z.M. and Rams, T.E. (2016) Non-oral gram-negative facultative rods in chronic periodontitis microbiota. Microb Pathogenesis, 94, 117-122. https://doi.org/10.1016/j.micpath.2016.01.020

33. Mashima, I. and Nakazawa, F. (2015) Interaction between Streptococcus spp. and Veillonella tobetsuensis in the early stages of oral biofilm formation. J Bacteriol, 197 (13), 2104-2111. http://doi.org/10.1128/JB.02512-14 
medRxiv preprint doi: https://doi.org/10.1101/2020.04.13.20064063; this version posted April 17, 2020. The copyright holder for this preprint (which was not certified by peer review) is the author/funder, who has granted medRxiv a license to display the preprint in perpetuity. All rights reserved. No reuse allowed without permission.

34. Eribe, E.R. and Olsen, I. (2017) Leptotrichia species in human infections II. J Oral Microbiol, 9(1), p.1368848. https://doi.org/10.1080/20002297.2017.1368848

35. Wen, Z.T., Liao, S., Bitoun, J.P., De, A., Jorgensen, A., Feng, S., Xu, X., Chain, P.S., Caufield, P.W., Koo, H. and Li, Y. (2017) Streptococcus mutans displays altered stress responses while enhancing biofilm formation by Lactobacillus casei in mixed-species consortium. Front Cell Infect Mi, 7, 524. https://doi.org/10.3389/fcimb.2017.00524 
medRxiv preprint doi: https://doi.org/10.1101/2020.04.13.20064063; this version posted April 17, 2020. The copyright holder for this preprint (which was not certified by peer review) is the author/funder, who has granted medRxiv a license to display the preprint in perpetuity.

All rights reserved. No reuse allowed without permission.

Table 1: Number of NGS reads, Simpson's and Shannon-Weaver alpha diversity indices of Nonchewers $(n=55)$ and Gutka chewers $(n=16)$.

\section{Number of NGS reads}

\section{Simpson's reciprocal index}

\section{Shannon-Weaver index}

\begin{tabular}{lllll}
\hline Non-chewers & Total & $4,175,739$ & 604.76 & 229.09 \\
\cline { 2 - 5 } & Average & $75,922 \mathrm{SD} \pm 43,448$ & $11.0 \mathrm{SD} \pm 4.6$ & $4.17 \mathrm{SD} \pm 0.6$ \\
\hline $\begin{array}{l}\text { Gutka } \\
\text { chewers }\end{array}$ & Total & 715,460 & 116.332 & 54.185 \\
\cline { 2 - 5 } & Average & $44,716 \mathrm{SD} \pm 15,629$ & $7.27 \mathrm{SD} \pm 3.03$ & $3.38 \mathrm{SD} \pm 0.7$ \\
\hline
\end{tabular}

\section{Figure Legends:}

Figure 1. Oral cavity lesions in chewers of betel nut preparation "Gutka".

Figure 2. VENN diagrammatic plot representing unique and shared salivary bacterial genera in non-chewers and Gutka chewers.

Figure 3. (a) Extended error bar plot representing Welch's t-test based differential abundance profile of bacterial phyla in non-chewers $(n=55)$ and Gutka chewers $(n=16)$ at $95 \%$ confidence interval with Storey's FDR correction. (b) Extended error bar plot representing Welch's t-test based differential abundance profile of bacterial genera in non-chewers $(\mathrm{n}=55)$ and Gutka chewers $(n=16)$ at $95 \%$ confidence interval with Storey's FDR correction.

Figure 4. Weighted uniFrac distance based PCoA plot of samples from non-chewers $(\mathrm{n}=55)$ and Gutka chewers $(\mathrm{n}=16)$. and $\bullet$ represent samples of Gutka chewers and non-chewers, respectively. 


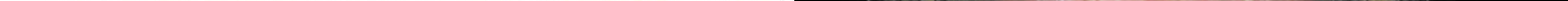


Non-chewers

Gutka chewers

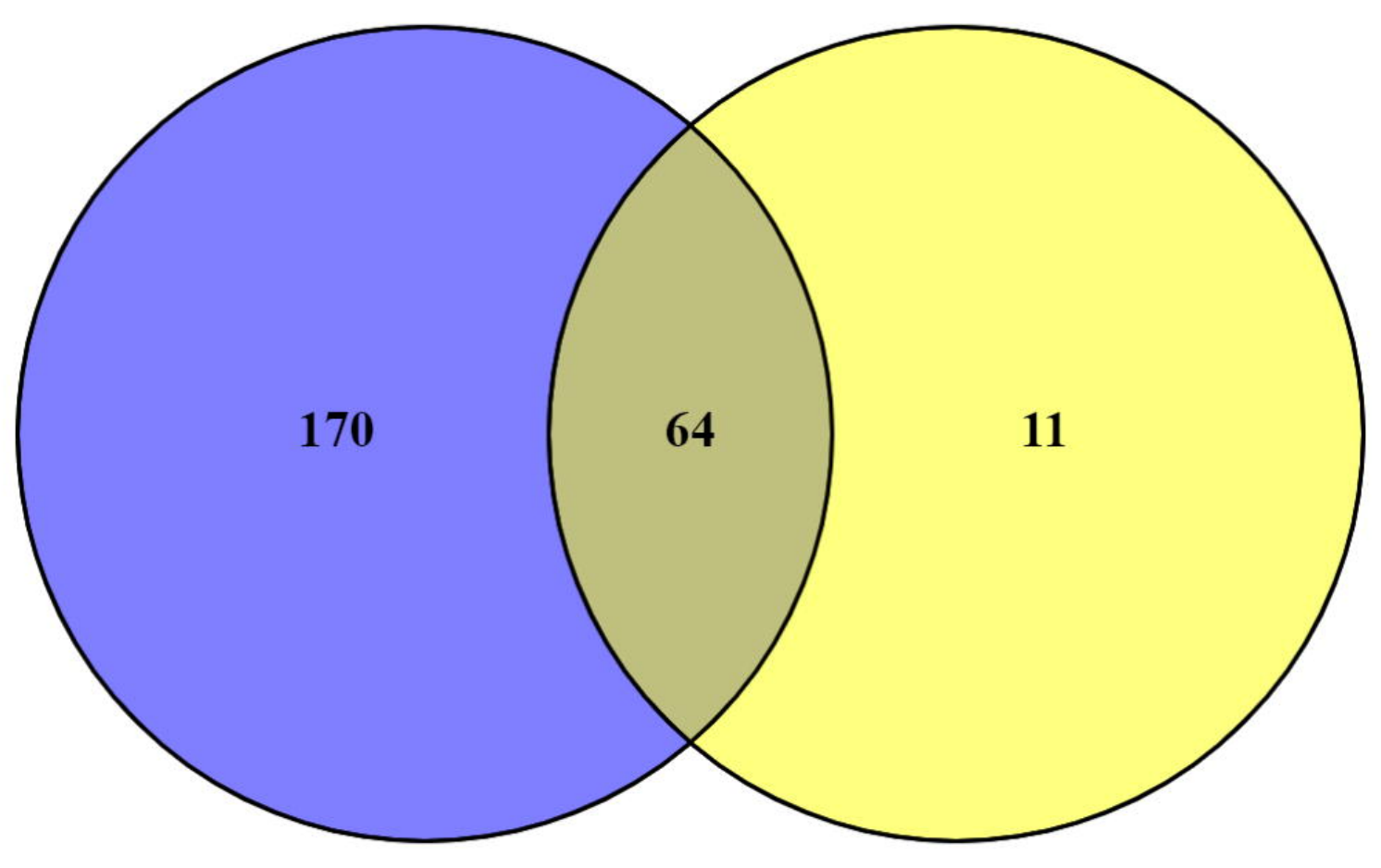




\section{$\square$ Gutka chewers $\square$ Non-chewers}

95\% confidence intervals

Firmicutes

Bacteroidetes

TM7

Actinobacteria 冒

Fusobacteria 局

Spirochaetes

Proteobacteria

Tenericutes |

Acidobacteria |

Synergistetes |

a
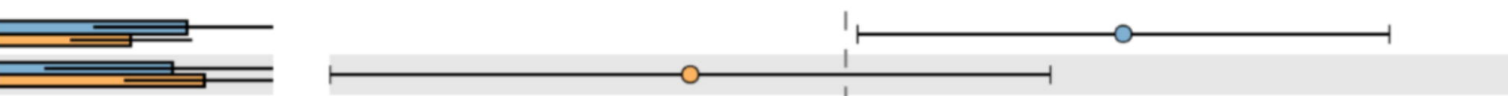

0.378

$5.77 \mathrm{e}-4$

0.431

0.483

0.351

0.949

0.680

$8.09 \mathrm{e}-3$

0.100

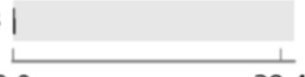

$38.4-15$

Mean proportion (\%)

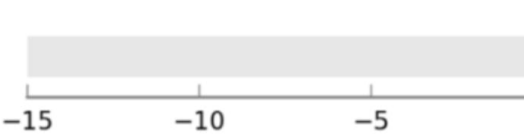

0

0

5

Difference in mean proportions (\%)

Gutka chewers $\square$ Non-chewers

$95 \%$ confidence intervals
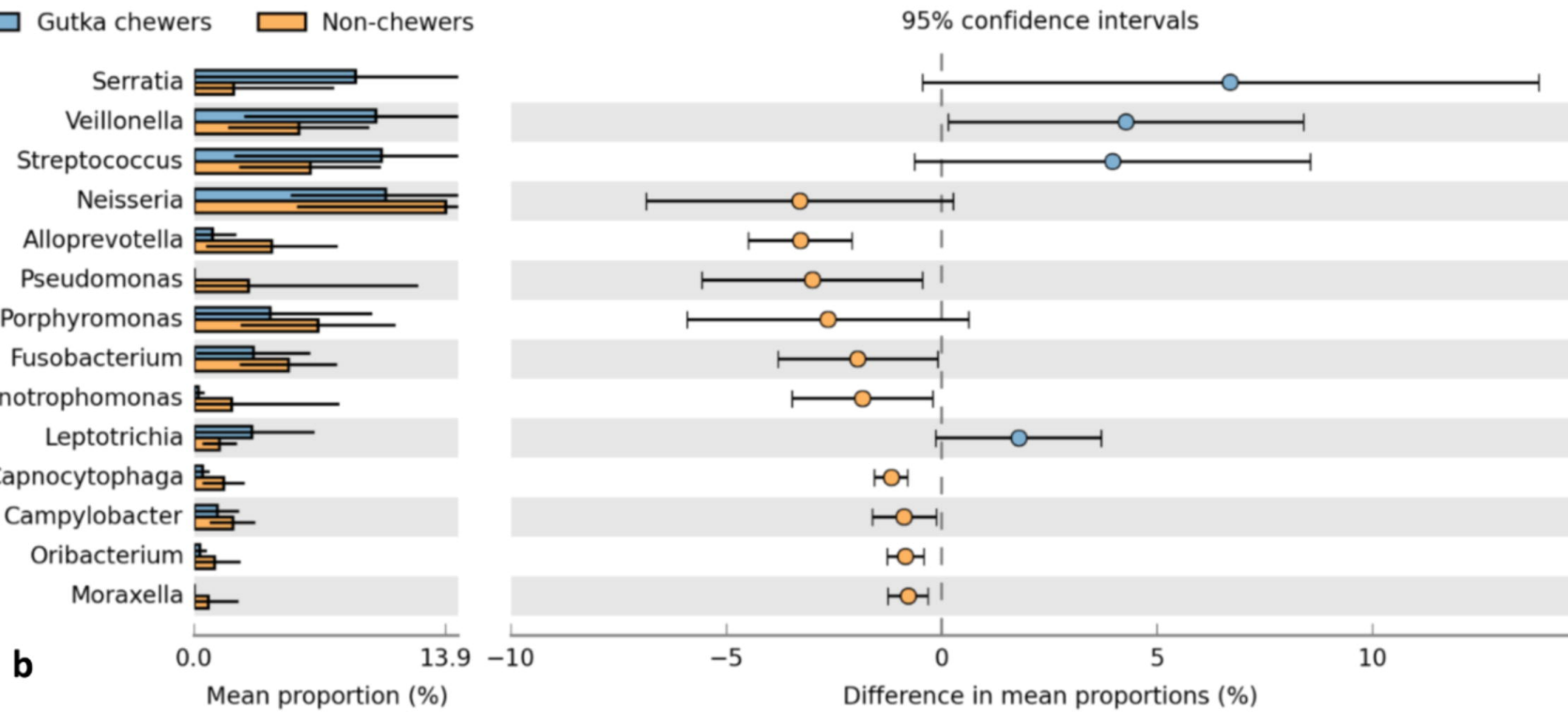

0.022

0.015

0.026

0.022

2.17e-6 -

0.011

0.031

0.015

0.012

0.022

$2.58 \mathrm{e}-7$

어

0.011

Campylobacter 专

Oribacterium

Moraxella

b
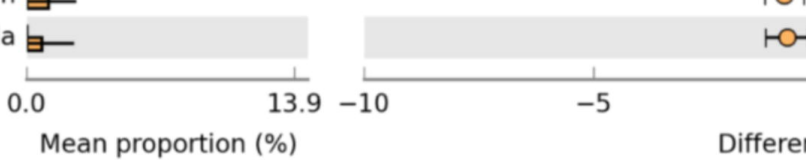

Difference in mean proportions (\%) 


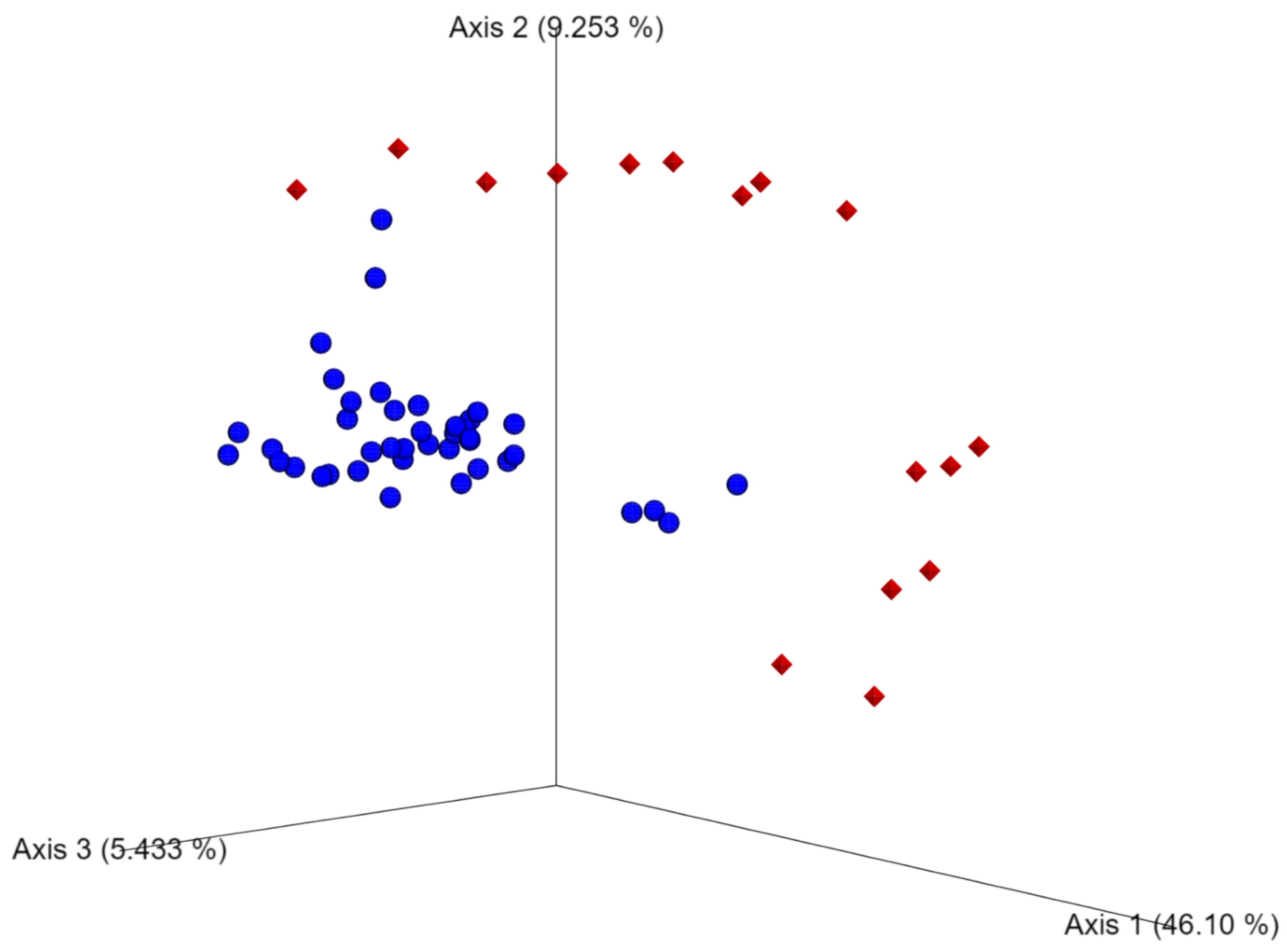

